\title{
Pathophysiology of Hypertrophic Pyloric Stenosis Revisited: The Use of Isotonic Fluid for Preoperative Infusion Therapy Is Supported
}

\author{
Ralf-Bodo Troebs \\ Klinik für Kinderchirurgie, Marien Hospital Herne, Ruhr University of Bochum, Bochum, Germany \\ Email: ralf-bodo.troebs@web.de
}

Received 20 June 2014; revised 15 July 2014; accepted 13 August 2014

Copyright (C) 2014 by author and Scientific Research Publishing Inc.

This work is licensed under the Creative Commons Attribution International License (CC BY).

http://creativecommons.org/licenses/by/4.0/

(c) (i) Open Access

\section{Abstract}

Background: The aim of this study was to elucidate the preoperative clinical and biochemical profile of infants with IHPS to optimize infusion therapy. Patients and Method: We retrospectively analyzed data from 56 infants who were operated for IHPS. Our study includes growth and laboratory data prior to the initiation of therapy. Results: Median duration of propulsive vomiting was 4 d; the median age was $37 \mathrm{~d}(18$ - 108), and the median body weight was $3840 \mathrm{~g}(2760$ - 5900). Metabolic alkalosis (MAlk) with a pH of $7.45 \pm 0.06$ and an st $\mathrm{HCO}_{3}^{-}$of $28.7 \pm 4.5 \mathrm{mmol} / \mathrm{l}$ was found. In a subgroup of the infants, negative base excess (BE) was observed. The sodium concentration was normal or reduced (mean/median of $137 \mathrm{mmol} / \mathrm{l}$ ). There was a strong negative correlation between st $\mathrm{HCO}_{3}^{-}$and $\mathrm{K}^{+}$. The carbon dioxide partial pressure tended to increase $(5.72 \pm 0.84 \mathrm{kPa})$. Calculations of osmolality revealed a normal osmolarity. Hypoglycemia did not occur. The creatinine clearance according to the Schwartz formula remained at a normal level $(85.3 \pm 24.3 \mathrm{ml} / \mathrm{min} /$ $1.73 \mathbf{~ m}^{2}$ ). Discussion: The presented case series is characterized by a short duration of preoperative vomiting. MAlk can be classified as a chloride deficiency syndrome. It is accompanied by normo- or hyponatremic dehydration with normal osmolality. Partial respiratory compensation occurred. A normal creatinine clearance indicated good glomerular renal function. Conclusion: The presented study supports the use of an isotonic infusion fluid with a low glucose concentration for preoperative infusion therapy.

\section{Keywords}

Infantile Pyloric Stenosis, Metabolic Alkalosis, Dehydration, Osmolality, Glucose, Lactate, Creatinine Clearance, Infusion Therapy 


\section{Introduction}

Infantile hypertrophic pyloric stenosis (IHPS) is the most common abdominal surgical condition in infants. The prevalence in Germany is 2.29 per 1000 live births [1]. IHPS is characterized by hypertrophy of the pyloric muscle, which results in gastric outlet obstruction. The typical presentation involves progressive, projectile, and nonbilious vomiting immediately following feeding. Palpability of the pylorus ("olive") and ultrasound imaging confirm the diagnosis [2]. The homeostasis is mainly disrupted by dehydration, metabolic alkalosis (MAlk), and catabolism [3] [4].

The pathogenesis of the pylorus tumor remains enigmatic. There is good evidence that the inherited hyperacidity caused by an immature feedback mechanism in gastric production is the predominant factor [5]. However, whether the elevation of serum gastrin is a primary or secondary phenomenon remains unclear.

Our study was designed to elucidate the clinical and biochemical characteristics of IHPS patients who received an early diagnosis. The aim was to analyze the acid-base status and electrolyte levels together with the glucose, lactate, and renal parameters. In particular, this study was performed to determine the type of dehydration that accompanied IHPS. These data were provided to define the baseline for optimized preoperative fluid management [6].

\section{Material and Methods}

Records of 66 infants who underwent an extramucosal pyloromyotomy between 2007 and 2010 were identified. The inclusion criteria were a clinical presentation, conformation of IHPS by ultrasound ( $100 \%$ of cases), and surgical treatment for IHPS. Data from 10 infants with IHPS were excluded from further analysis (lack of acid-base analysis at admission [ $\mathrm{n}=8]$, hydrops fetalis, and history of previous operation).

Data from 56 infants (45 male, 11 female) met the criteria for further investigation. The gestational age (GA), birth weight, age at admission, body weight (BW), and length (BL) were extracted from the records. Any infant born before 37 weeks (wk) of gestation was defined as preterm. The gain of weight (GW) was estimated as the difference between the BW at admission and the birth weight. For biochemical investigations, we used the results of the routine laboratory assessment prior to the initiation of therapy. The biochemical spectrum included the hemoglobin concentration $(\mathrm{Hb})$, hematocrit $(\mathrm{Hct})$, acid-base status ( $\mathrm{pH}$, base excess [BE], partial pressure of carbon dioxide $\left[\mathrm{pCO}_{2}\right]$, and standard bicarbonate $\left[\mathrm{HCO}_{3}^{-}\right]$), and ion concentrations (sodium $\left[\mathrm{Na}^{+}\right]$, potassium $\left[\mathrm{K}^{+}\right]$, calcium $\left[\mathrm{Ca}^{++}\right]$, and chloride $\left[\mathrm{Cl}^{-}\right]$). In addition, data on the serum concentrations of glucose, lactate, creatinine, and urea were collected. For reference, we used the values from age matched-patients in our hospital in accordance with the literature [7]-[8]. The data are expressed in SI units.

Calculated parameters. The anion gap (AG) was defined as the difference between the anions and cations:

$$
\mathrm{AG}=\left(\mathrm{Na}^{+}+\mathrm{K}^{+}\right)-\left(\mathrm{Cl}^{-}+\mathrm{HCO}_{3}^{-}\right)[9] .
$$

The theoretical serum osmolality (OSM) was calculated according the equation OSMc $=2 \mathrm{Na}^{+}+$glucose + urea [mmol/l] [7], and for a more detailed estimation, we used the following formula: OSMc $=1.86\left(\mathrm{Na}^{+}+\mathrm{K}^{+}\right)+$ 1.15 glucose + urea +14 [mosm $/ \mathrm{kg}][10]$.

The creatinine clearance $\left(\mathrm{C}_{\mathrm{cr}}\right)$ was estimated using the Schwartz formula [11]:

$\mathrm{C}_{\mathrm{cr}}\left[\mathrm{ml} / \mathrm{min} / 1.73 \mathrm{~m}^{2}\right]=0.45 \times \mathrm{BL}[\mathrm{cm}] / \mathrm{creatinine}[\mathrm{mg} / \mathrm{dl}]($ creatinine $[\mathrm{mg} / \mathrm{dl}]=\mu \mathrm{mol} / / / 88.4)$.

\subsection{Limits}

The presented study has some limits. It is based on a retrospective chart review and data analysis. Furthermore, some data were missing, and some terms (e.g., propulsive vomiting) were not precisely defined. Blood samples were tested. The laboratory results are based on the analysis of capillary blood (CB) in 4/5 of the infants and venous blood (VB) in 1/5. The gold standard for blood gas analysis is the use of arterial blood. However, $\mathrm{CB}$ samples are routinely used to estimate the acid-base balance and the levels of ions, glucose, and lactate with commercially available blood gas analyzers [12]. All analyzers underwent sequential calibrations and quality controls by the "Ring Trial". For the acid-base analysis $\left(\mathrm{pCO}_{2}, \mathrm{pH}\right.$, and $\left.\mathrm{BE}\right)$, evidence suggests a good correlation between arterial and capillary or venous samples. However, in arterialized $\mathrm{CB}$ or VB, the $\mathrm{pH}$ is lower by an average of 0.05 , and the $\mathrm{pCO}_{2}$ may be higher [7]. 


\subsection{Statistics}

Data are expressed as the arithmetic mean \pm standard deviation (SD), the median value, and/or the minimum/maximum (noted in parentheses). A significant difference between the median and mean indicates a skewed distribution. For the statistical analysis, we used linear regression analysis and Pearson's correlation coefficient (Table 4). The significance level for the correlation coefficient was tested for (n-2) degrees of freedom.

\section{Results}

\subsection{Biometrics (Table 1)}

The male to female ratio was 4:1. The median BW was $3200 \mathrm{~g}(1990$ - 4300), and we found a median gestational age of 38 weeks (33 - 41). Fourteen infants were preterm, with a GA between 33 and 36 wk. The median GW from birth to admission remained at $578 \mathrm{~g}(-160$ - 2160). However, 19 infants had a GW less than $500 \mathrm{~g}$ (including 4 with BW below birth weight). The series included three sets of twins, and both partners were affected in one twin set. The median duration of propulsive vomiting was 4 days (1 - $28 \mathrm{~d})$. At the time of the operation the median age was $37 \mathrm{~d}(18$ - 108), and the median BW at admission was $3840 \mathrm{~g}(2760$ - 5900). The median body length was $54 \mathrm{~cm}(49-61)$.

\subsection{Biochemical Profile (Table 2 and Table 3)}

Acid-base balance. As expected, the majority of the IHPS patients showed an elevated st $\mathrm{HCO}_{3}^{-}$of $28.7 \pm 4.5$ $\mathrm{mmol} / \mathrm{l}(27.9 ; 21$ - 41), and the $\mathrm{pH}$ was $7.45 \pm 0.06$ (7.45; 7.32 - 7.65). In the majority of patients, MAlk was partially compensated by a $\mathrm{pCO}_{2}$ increase to $5.72 \pm 0.84 \mathrm{kPa}$ (5.73; 3.27 - 8.36). Hypercapnia with $\mathrm{pCO}_{2}>6.5$ $\mathrm{kPa}$ occurred in 6 infants. The $\mathrm{BE}$ was $>3 \mathrm{mmol} / \mathrm{l}$ in $58 \%$ of the patients. A negative BE was found in a subgroup of 5 infants (i.e., BE values of $-0.1,-0.2,-1,-4,-4 \mathrm{mmol} / \mathrm{l})$. These patients were characterized by the following median parameters: st $\mathrm{HCO}_{3}^{-}$of $22.9 \mathrm{mmol} / \mathrm{l}, \mathrm{pCO}_{2}$ of $5.0 \mathrm{kPa}, \mathrm{pH}$ of 7.36 , anion gap of $16.3 \mathrm{mmol} / \mathrm{l}$, and lactate level of $3.4 \mathrm{mmol} / \mathrm{l}$.

Hemoglobin and hematocrit. The Hb and Hct values were $13.1 \pm 2.4(12.8 ; 9.1$ - 17.8) and $37.9 \pm 6.52$ $\mathrm{mmol} / \mathrm{dl}(36.5 ; 27$ - 54.7), respectively.

Electrolytes. The range of the blood cations was mainly within normal limits: the $\mathrm{Na}^{+}$concentration was $137 \pm$ $2.49 \mathrm{mmol} / \mathrm{l}\left(137 ; 130\right.$ - 144). Six infants had a slightly reduced $\mathrm{Na}^{+}$concentration: $<135 \mathrm{mmol} / \mathrm{l}$. The infants presented with a $\mathrm{K}^{+}$concentration of $4.7 \pm 0.83 \mathrm{mmol} / \mathrm{l}$ (4.8; 3.1 - 7.2); 19 infants had $\mathrm{K}^{+}>5 \mathrm{mmol} / \mathrm{l}$, but no infants had levels below $3 \mathrm{mmol} / \mathrm{l}$. Ca was estimated as the total Ca of $2.8 \pm 0.68 \mathrm{mmol} / \mathrm{l}(2.7 ; 2.4-5.2)$ and the $\mathrm{Ca}^{++}$of $1.29 \pm 0.14 \mathrm{mmol} / \mathrm{l}(1.34 ; 0.87-1.42)$.

The $\mathrm{Cl}^{-}$level was estimated in 22 infants with a value of $98 \pm 7.56 \mathrm{mmol} / \mathrm{l}(101 ; 83-108)$. From the difference between the cations and anions, we derived a mean AG of $13.1 \pm 3.5 \mathrm{mmol} / \mathrm{l}(12.8 ; 5.8$ - 19.9). In 6 infants, the AG was below $12 \mathrm{mosm} / \mathrm{l}$, and in 2 infants, it was above $17 \mathrm{mosm} / \mathrm{l}$.

Glucose and lactate levels, and creatinine clearance. The glucose level was $5.11 \pm 0.62 \mathrm{mmol} / \mathrm{l}(5.05 ; 4$ 6.72). We found a serum lactate of $2.0 \pm 0.95 \mathrm{mmol} / \mathrm{l}(1.8 ; 0.8-9.8)$. Seven infants had an elevated serum lactate of $>2.5 \mathrm{mmol} / \mathrm{l}$. The creatinine remained at $0.32 \pm 0.08 \mathrm{mg} / \mathrm{dl}(0.30 ; 0.17-0.52)$, and the $\mathrm{C}_{\text {cr }}$ calculated from the Schwartz formula was $85.3 \pm 24.3 \mathrm{ml} / \mathrm{min} / 1.73 \mathrm{~m}^{2}$ (85.2; 54 - 161.5).

\begin{tabular}{|c|c|c|c|c|}
\hline Parameter & Median & Min-Max & Mean & SD \\
\hline Birth weight [g] & 3200 & $1990-4300$ & 3253 & 547 \\
\hline Gestat. age [weeks] & 38 & $33-41$ & 38 & 2.5 \\
\hline Duration of vomiting [days] & 4 & $1-28$ & 6 & 19 \\
\hline Weight gain since birth & 578 & $(-260-2160)$ & 767 & 438 \\
\hline Age at OP [days] & 37 & $18-108$ & 39 & 20.2 \\
\hline Body weight at OP [g] & 3840 & $2760-5900$ & 3992 & 757 \\
\hline Body length $[\mathrm{cm}]$ & 54 & $49-61$ & 55 & 3.27 \\
\hline
\end{tabular}


Table 2. Acid-base status, ion concentrations, anion gap, and osmolarity.

\begin{tabular}{|c|c|c|c|c|c|c|}
\hline Parameter & $\mathrm{N}$ & Med & Min-Max & Mean & $\mathrm{SD}$ & Reference Values (RV) \\
\hline $\mathrm{pH}$ & 55 & 7.45 & $7.32-7.65$ & 7.45 & 0.06 & $7.33-7.45$ \\
\hline $\mathrm{BE}[\mathrm{mmol} / \mathrm{l}]$ & 55 & 3.8 & $-4.0-17.9$ & 5.2 & 4.98 & -3 to +3 \\
\hline St $\mathrm{HCO}_{3}^{-} \quad[\mathrm{mmol} / \mathrm{l}]$ & 51 & 27.9 & $21.0-41.0$ & 28.7 & 4.48 & $18.2-25$ \\
\hline $\mathrm{pCO}_{2}[\mathrm{kPa}]$ & 53 & 5.73 & $3.72-8.36$ & 5.72 & 0.84 & $4.5-6.5$ \\
\hline $\mathrm{Hb}[\mathrm{mmol} / \mathrm{l}]$ & 53 & 7.95 & $5.65-11.05$ & 8.14 & 1.27 & Age dependent \\
\hline Hct [\%] & 53 & 36.5 & $27.0-54.7$ & 37.9 & 6.52 & $31-59$ \\
\hline $\mathrm{Na}^{+}[\mathrm{mmol} / \mathrm{l}]$ & 53 & 137 & $130-144$ & 137 & 2.49 & $135-145$ \\
\hline $\mathrm{K}^{+}[\mathrm{mmol} / \mathrm{l}]$ & 53 & 4.8 & $3.1-7.2$ & 4.7 & 0.83 & $3.5-5.0$ \\
\hline $\mathrm{Ca}^{++}[\mathrm{mmol} / \mathrm{l}]$ & 24 & 1.34 & $0.87-1.42$ & 1.29 & 0.14 & $1.1-1.3$ \\
\hline Ca total $[\mathrm{mmol} / \mathrm{l}]$ & 27 & 2.7 & $2.4-5.2$ & 2.8 & 0.68 & $2.2-2.7$ \\
\hline $\mathrm{Cl}^{-}[\mathrm{mmol} / \mathrm{l}]$ & 22 & 101 & $83-108$ & 98 & 7.56 & 95 to 108 \\
\hline Anion gap [mmol/l] & 21 & 12.8 & $5.8-19.9$ & 13.1 & 3.5 & $<12-17$ \\
\hline Osmol $^{*}[\mathrm{mosm} / \mathrm{l}]$ & 14 & 280 & $269-290$ & 280 & 9.2 & $270-295$ \\
\hline Osmol $^{* *}[\mathrm{mosm} / \mathrm{kg}]$ & 14 & 285 & $274-295$ & 283 & 10.4 & $282-302$ \\
\hline
\end{tabular}

* according to [7]; ${ }^{* *}$ according to [10].

Table 3. Serum concentrations of metabolites and renal parameters.

\begin{tabular}{ccccccc}
\hline Parameter & N & Median & Min-Max & Mean & SD & Reference Values \\
\hline Glucose $[\mathrm{mmol} / \mathrm{l}]$ & 50 & 5.05 & $4.00-6.72$ & 5.11 & 0.62 & $2.6-6.60$ \\
Lactate $[\mathrm{mmol} / \mathrm{l}]$ & 27 & 1.8 & $0.8-3.9$ & 2.0 & 0.95 & $<2.5$ \\
Creatinine $[\mu \mathrm{mol} / \mathrm{l}]$ & 27 & 26.52 & $15.03-45.97$ & 28.29 & 7.07 & $<44.2$ \\
Crea-Clearance $\left[\mathrm{ml} / \mathrm{min} / 1.73 \mathrm{~m}^{2}\right]$ & 22 & 85.2 & $54-161.5$ & 85.3 & 24.3 & $41-91^{*}$ \\
Urea $[\mathrm{mmol} / \mathrm{l}]$ & 16 & 2.91 & $0.83-4.80$ & 2.86 & 1.01 & $1.35-2.33$ \\
\hline
\end{tabular}

"according to [13].

Osmolality (OSM). We found normal or slightly elevated levels of urea: $(\mathrm{n}=16) 2.86 \pm 1.01 \mathrm{mmol} / \mathrm{l}(2.91$; 0.83 - 4.80). The OSM calculated using the standard formula was $280 \pm 9.19 \mathrm{mmol} / \mathrm{l}(280 ; 269-290)$. Using the improved formula, which is described elsewhere [15], we found $283 \pm 10.4 \mathrm{mosm} / \mathrm{kg}$.

\subsection{Ethics}

The Research Ethics Board of the Ruhr-University of Bochum (4271-12) approved the study.

\section{Discussion}

The pathogenesis of IHPS is multifactorial and includes hypergastrinemia, abnormal pyloric innervation, genetic mutations, and environmental influences [5] [14]. This study was performed in Nordrhein-Westfalen (NRW). In this area, the prevalence of IHPS declined from 3.88 to 2.30 per 1000 live births from 2000 to 2008 [1]. We found a predominance of males with a 4:1 ratio, which was consistent with the literature [2] [13] [15] [16]. Most of the IHPS infants were mature with a normal gestation and age-appropriate birth weight [10] [17] [18]. However, up to $1 / 4$ of the patients were premature [9] [13] [14] [16]. The median duration of propulsive vomiting was $4 \mathrm{~d}$, which was shorter than that in previous clinical series [2] [14]-[16]. In concordance with the literature, the vast majority of infants presented to the hospital at the age of 5 to $6 \mathrm{wk}$. Due to a lack of data on the body weight before the initiation of propulsive vomiting, we were not able to estimate the weight loss for the period prior to admission. In our cohort, the median GW since birth was $585 \mathrm{~g}$, with significant variability. As a rule, 
the BW in healthy infants increases $200 \mathrm{~g}$ per week in the first trimester [19], i.e., $1000 \mathrm{~g}$ in the first 5 wk. Thus, the majority of our patients showed a marked weight deficiency.

Preoperative replacement of water and electrolytes is the main step in the preoperative therapy for IHPS. Under the condition of perioperative stress, non-osmotic stimulation with antidiuretic hormone (ADH) may result in water intoxication and hyponatremia. Thus, it has been shown that the use of hypotonic fluids is associated with an elevated risk of hyponatremia. To prevent this rare but serious complication, the use of isotonic solutions has been recommended for perioperative fluid substitution in surgically ill infants [12] [20].

According to the Henderson-Hasselbalch equation, the blood $\mathrm{pH}$ is determined by the ratio between $\mathrm{HCO}_{3}^{-}$ and $\mathrm{pCO}_{2}$. An elevation of $\mathrm{HCO}_{3}^{-}$, and therefore alkalemia, are the hallmarks of MAlk. We found a strong positive correlation between st $\mathrm{HCO}_{3}^{-}$and $\mathrm{pH}$ (Table 4).The present study confirms the decreased $\mathrm{Cl}^{-}$levels that result from vomiting. Our results are consistent with previous investigations reporting 10 to $49 \%$ of infants with $\mathrm{Cl}^{-}$concentrations of $<90$ to $98 \mathrm{mmol} / \mathrm{l}$ [2]. The chloride concentration correlated negatively with st $\mathrm{HCO}_{3}^{-} \quad(\mathrm{p}=$ 0.001, Table 4), indicating increasing alkalosis with the progressive loss of $\mathrm{Cl}^{-}$. The alkalosis associated with IHPS can be classified as the type that accompanies $\mathrm{Cl}^{-}$deficiency syndrome, [7] i.e., $\mathrm{Cl}^{-}$is lost from the transcellular compartment with an accompanying loss of $\mathrm{H}^{+}$, and $\mathrm{K}^{+}$, and to a lesser extent, $\mathrm{Na}^{+}$.

In our series, the infants presented with st $\mathrm{HCO}_{3}^{-}>25 \mathrm{mmol} / \mathrm{l}$, and $46 \%$ of the infants showed enhanced alkalemia: $>28 \mathrm{mmol} / \mathrm{l}$. Thus, our rate seems to be higher than that in a recent meta-analysis in which an initial severe alkalosis with $\mathrm{HCO}_{3}^{-}>28$ to $30 \mathrm{mmol} / \mathrm{l}$ was reported in $9 \%$ to $37 \%$ of infants [2]. Hypovolemia and hypochloremia are two additional factors leading to increased $\mathrm{HCO}_{3}^{-}$levels via renal mechanisms.

IHPS typically presents with a positive BE. Surprisingly, we found a subgroup of 5 infants with a negative BE, indicating a lack of buffer bases. This subgroup showed compensated $\mathrm{pH}$ and $\mathrm{HCO}_{3}^{-}$at the low end of the normal range, low $\mathrm{Hb}$, and elevated lactate levels. The Hb-OxyHb system is one of the most powerful buffer systems; thus, the negative BE may be enhanced by anemia.

In this investigation, we used the in vitro generated "artificial" parameters for st $\mathrm{HCO}_{3}^{-}$and BE. Both are often used in clinical practice. However, BE may be misleading in some instances. For atypical ABA results, a differential diagnosis must account for gastroesophageal reflux (GER), and in rare cases, for an inborn error of metabolism and salt loss from adrenogenital syndrome [21] [22].

All infants with IHPS lose potassium due to vomiting and enhanced renal excretion [23]. Compared with blood, gastric juice contains lower amounts of $\mathrm{Na}^{+}(51 \mathrm{mmol} / \mathrm{l})$ and higher amounts of $\mathrm{K}^{+}(11.7$ to $25 \mathrm{mmol} / \mathrm{l})$. Thus, vomiting mainly results in the loss of fluid that is rich in both $\mathrm{K}^{+}$and $\mathrm{Cl}^{-}$. The compensatory shift of

Table 4. Regression $(y=A x+B)$ and correlation analysis of biochemical parameters.

\begin{tabular}{|c|c|c|c|c|}
\hline Correlation & $\mathrm{N}$ & A & $\mathrm{r}$ & $\mathrm{p}$ \\
\hline $\mathrm{Hb}$ - age & 50 & -0.06 & -0.53 & 0.001 \\
\hline Hct - st bicarb & 47 & 0.452 & 0.32 & 0.05 \\
\hline $\mathrm{pCO}_{2}$ - st bicarb & 47 & 0.616 & 0.42 & 0.01 \\
\hline $\mathrm{Na}-\mathrm{Cl}$ & 22 & $\#$ & 0.31 & n.s. \\
\hline $\mathrm{Na}$ - st bicarb & 47 & \# & -0.20 & n.s. \\
\hline K - st bicarb & 47 & -0.108 & -0.59 & 0.001 \\
\hline $\mathrm{Ca}^{++}-\mathrm{pH}$ & 24 & -0.862 & -0.42 & 0.05 \\
\hline $\mathrm{Cl}$ - st bicarb & 21 & -1.259 & -0.88 & 0.001 \\
\hline pH - st bicarb & 47 & 0.009 & 0.71 & 0.001 \\
\hline Lact - st bicarb & 27 & -0.084 & -0.39 & 0.05 \\
\hline Lact - pH & 27 & \# & -0.19 & n.s. \\
\hline $\mathrm{AG}-\mathrm{pH}$ & 21 & -25.04 & -0.457 & 0.05 \\
\hline$A G-B E$ & 21 & $\#$ & 0.076 & n.s. \\
\hline Urea - st bicarb & 15 & \# & -0.02 & n.s. \\
\hline Urea - pH & 16 & \# & 0.27 & n.s. \\
\hline
\end{tabular}

n.s.-no significance; \#-useless. 
intracellular $\mathrm{H}^{+}$into the extracellular space and the reverse shift of $\mathrm{K}^{+}$favors the hypokalemia that is characteristic of MAlk. In addition, the reduced circulation volume may activate the renin-angiotensin-aldosterone system, resulting in $\mathrm{Na}^{+}$reabsorption and renal $\mathrm{K}^{+}$loss. However, these mechanisms appear to be less important in infants [24]. In concordance with the results of a previous study [15], a correlation analysis confirmed a strong

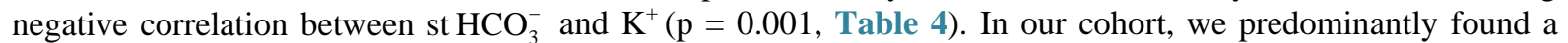
highly normal serum $\mathrm{K}^{+}$concentration, and less than $10 \%$ of the infants had values below $3.5 \mathrm{mmol} / \mathrm{l}$. To explain our results, the bias when using capillary blood to estimate $\mathrm{K}^{+}$must be taken into account. Compared with VB, $\mathrm{CB}$ tends to have a higher $\mathrm{K}^{+}$concentration. This difference is caused by the difficulty in collecting blood from dehydrated infants, the influence of the $\mathrm{K}^{+}$-rich cytosol of hemolytic red cells, and the addition of interstitial fluid, which contains $7 \%-8 \%$ more $\mathrm{K}^{+}$as a result of the Gibbs-Donnan equilibrium [19]. In previous investigations, a low $\mathrm{K}^{+}$concentration was associated with a high $\mathrm{HCO}_{3}^{-}$concentration [16], and a highly significant trend of reduced $\mathrm{K}^{+}$was observed as the duration of the symptoms and the dehydration increased [13].

Calcium is another important cation. In the case of MAlk, a shift from $\mathrm{Ca}^{++}$to the protein-bound form is expected. Accordingly, we found a weak negative influence of $\mathrm{pH}$ on the plasma $\mathrm{Ca}^{++}(\mathrm{p}=0.05)$ [7].

Water and electrolyte disturbances result from the loss of fluid and electrolytes and from the movement of water and electrolytes between body compartments. The weak correlation between Hct and st $\mathrm{HCO}_{3}^{-}(\mathrm{p}=0.05)$ indicated increased Hct with an elevation of $\mathrm{HCO}_{3}^{-}$due to water loss (Table 4). In our patients, Hct was not helpful for determining the degree of dehydration.

Sodium plays a key role in extracellular fluid (ECF) volume regulation. An increased sodium concentration indicates that the ECF is becoming concentrated. In our cohort, we found a normally distributed $\mathrm{Na}^{+}$concentration around the mean/median of $137 \mathrm{mmol} / \mathrm{l}$ with a trend toward hyponatremia. The sodium concentration did not correlate with the $\mathrm{Cl}^{-}$concentration. The $\mathrm{Na}^{+}$and st $\mathrm{HCO}_{3}^{-}$concentrations were inversely related (n.s.; Table 4). These results correspond to those of a previous study [16]. Others described a slow decline in $\mathrm{Na}^{+}$concentration as the symptoms persisted [13] and a negative correlation between the $\mathrm{Na}^{+}$and $\mathrm{HCO}_{3}^{-}$levels [15]. In a recent Chinese study, hyponatremia was found in 54\% of infants with IHPS [8]. In rare instances, IHPS can be associated with dehydration and severe hyponatremia due to pseudo Bartter's syndrome [7].

Osmolality is defined as the molar concentration of all of the solutes in a given weight of water. The most important solute for the OSM is sodium salts, whereas other ions, glucose, and urea contribute to a lesser extent. In clinical practice, OSM is measured per liter of solution (molar) rather than per kg of solvent (molal). In our investigation, we used two different formulas to calculate the OSM. In infants with IHPS, we found a theoretical OSM of $280 \pm 92 \mathrm{mmol} / \mathrm{l}$ or $283 \pm 10.4 \mathrm{mosm} / \mathrm{kg}$ (iso-osmolar). Thus, these results indicate the presence of normotonic-normonatremic/hyponatremic dehydration in IHPS.

The anion gap provides important information for further differentiation of the underlying acid-base disturbance [7]. AG reflects the unmeasured anions and cations. Correlation analysis revealed a negative correlation between $\mathrm{pH}$ and AG ( $\mathrm{p}=0.05$; Table 4). It can be assumed that the AG in IHPS is mainly influenced by the increase in $\mathrm{HCO}_{3}^{-}$, the loss of $\mathrm{Cl}^{-}$, and the production of organic acids (lactate, acetoacetate, and $\beta$-hydroxybutyrate). Ketonuria in IHPS has been reported previously [16].

In some patients, lactate was present in elevated amounts. This finding might result from tissue hypoperfusion and anaerobic metabolism. Lactate may serve as a fuel for gluconeogenesis in the liver and kidney and thus stabilize glucose levels. In our study, the correlation between lactate and either $\mathrm{HCO}_{3}^{-}$or $\mathrm{pH}$ was weak or non-existent (Table 4). Whether the combination of stress, low Hb, and the left shift of the oxygen-hemoglobin dissociation curve caused by alkalosis contributed to the elevated lactate levels remains unknown. As expected, we found low $\mathrm{Hb}$ concentrations and a negative correlation between age and $\mathrm{Hb}$.

The physiological respiratory compensatory mechanism for MAlk is clinically important. The decreased $\mathrm{H}^{+}$ results in a decrease in ventilation and hypercapnia. This effect is most often neutralized by the physiological stimulation of chemoreceptors in response to the increased $\mathrm{pCO}_{2}$ and decreased $\mathrm{pO}_{2}$; this stimulation restores the ventilatory drive. However, clinical reports have described life-threatening respiratory depression in IHPS, with symptoms including apnea, desaturation, and bradycardia [25] [26]. The majority of our patients presented with $\mathrm{pCO}_{2}$ values that were elevated to the high end of the normal range. We found a good positive correlation between st $\mathrm{HCO}_{3}^{-}$and $\mathrm{pCO}_{2}\left(\mathrm{p}=0.01\right.$; Table 4). Feng et al. reported elevated $\mathrm{HCO}_{3}^{-}$and $\mathrm{pCO}_{2}$ in a late-onset group (2014). However, serious respiratory problems in IHPS are rare. Nonetheless, pulse oximetry is advised for IHPS patients.

The kidney is extraordinarily important for regulating the ECF volume and acid-base balance. For clinical 
purposes, the glomerular filtration rate (GFR) can be quantified by estimating the creatinine clearance. Physiological maturation of the kidney is accompanied by a threefold increase in GFR during the first trimester. The Schwartz formula value of $\mathrm{C}_{\mathrm{cr}}$ provides good information on glomerular function in children [11]. We only found normal $\mathrm{C}_{\mathrm{cr}}$ values, which indicated a normal, age-appropriate GFR.

Urea is a product of protein catabolism. Ammonia is incorporated into urea, and it is excreted by the kidney. Theoretically, the increased blood $\mathrm{pH}$ in alkalosis increases urea synthesis within the liver and leads to increased filtration of $\mathrm{HCO}_{3}^{-}$[18]. In a previous study, the urea level was elevated in the IHPS group but not in the GER group [27]. In our small series, a regression analysis did not reveal any correlation between urea and either $\mathrm{pH}$ or $\mathrm{HCO}_{3}^{-}$(Table 4). In a previous investigation, neither the creatinine nor the urea concentration reflected the degree of dehydration in IHPS [4].

Hypoglycemia as a result of hepatic glucose depletion has been described postoperatively in IHPS [22] [28]. However, none of our patients presented with a blood glucose level below $4.0 \mathrm{mmol} / \mathrm{l}$. The glycogen stores of a fasting neonate will be exhausted within 12 to 24 hours. In infants, energy is mainly stored as fat, and the fat reserves of a term infant may be sufficient for a 21-day fast [29]. Thus, fatty acid oxidation is the most important provider of energy to support gluconeogenesis and stabilize blood glucose levels in fasting infants [18]. In exceptional cases, severe hypoglycemia as a result of neonatal hyperinsulinism in association with IHPS has been reported [30]. Early postoperative feeding with continuous intravenous electrolyte and glucose supplementation is effective at preventing hypoglycemia and the subsequent adverse neurodevelopment [9].

\section{Conclusion}

In conclusion, we presented a series of IHPS patients with a short duration of vomiting. MAlk, hypochloremia, increased $\mathrm{pCO}_{2}$ iso- or mild hypotonic dehydration, and normoglycemia were the most important findings at admission. These data support the use of an isotonic solution with a low glucose concentration for preoperative fluid substitution in infants with IHPS.

\section{References}

[1] Laffolie, J., Turial, S., Heckmann, M., et al. (2012) Decline in Infantile Hypertrophic Pyloric Stenosis in Germany in 2000-2008. Pediatrics, 129, e901-e906. http://dx.doi.org/10.1542/peds.2011-2845

[2] Glatstein, M., Carbell, G., Boddu, S.K., et al. (2011) The Changing Clinical Presentation of Hypertrophic Pyloric Stenosis: The Experience of a Large, Tertiary Care Pediatric Hospital. Clinical Pediatrics, 50, 192-195. http://dx.doi.org/10.1177/0009922810384846

[3] Clark, R.G. and Norman, J.N. (1964) Metabolic Alkalosis in Pyloric Stenosis. Lancet, 1, 1244-1245. http://dx.doi.org/10.1016/S0140-6736(64)91869-0

[4] Dawson, K.P. and Graham, D. (1991) The Assessment of Dehydratation in Congenital Pyloric Stenosis. The New Zealand Medical Journal, 104, 162-163.

[5] Rogers, I.M. (2006) The True Cause of Pyloric Stenosis Is Hyperacidity. Acta Paediatrica, 95, 132-136. http://dx.doi.org/10.1111/j.1651-2227.2006.tb02197.x

[6] Foster, B.A., Tom, D. and Hill, V. (2014) Hypotonic versus Isotonic Fluids in Hospitalized Children: A Systematic Review and Meta-Analysis. The Journal of Pediatrics, 165, 163-169. http://dx.doi.org/10.1016/j.jpeds.2014.01.040

[7] Bianchetti, M.G. and Bettinelli, A. (2008) Differential Diagnosis and Management of Fluid, Electrolyte, and Acid-Base Disorders. In: Geary, D.F. and Schaefer, F., Eds., Comprehensive Pediatric Nephrology. Mosby/Elsevier, Philadelphia. http://dx.doi.org/10.1016/B978-0-323-04883-5.50033-7

[8] Fox, G., Hoque, N. and Watts, T. (2010) Oxford Handbook of Neonatology. Oxford University Press, Oxford, New York.

[9] Graham, D.A., Mogride, N., Abbott, G.D., et al. (1993) Pyloric Stenosis: The Christchurch Experience. The New Zealand Medical Journal, 106, 57-59.

[10] Khajuria, A. and Krahn, J. (2005) Osmolality Revisited—Deriving and Validating the Best Formula for Calculated Osmolality. Clinical Biochemistry, 38, 514-519. http://dx.doi.org/10.1016/j.clinbiochem.2005.03.001

[11] Hogg, R.J., Furth, S., Lemley, K.V., et al. (2003) National Kidney Foundation's Disease Outcomes Quality Initiative Clinical Practice Guidelines for Chronic Kidney Disease in Children and Adolescents: Evaluation, Classification and Stratification. Pediatrics, 111, 1416-1421. http://dx.doi.org/10.1542/peds.111.6.1416

[12] Tan, S. and Campbell, M. (2008) Acid-Base Physiology and Blood Gas Interpretation in the Neonate. Paediatrics and 
Child Health, 18, 172-177. http://dx.doi.org/10.1016/j.paed.2007.12.013

[13] Beasley, S.W., Hudson, I., Hok Pan, Y., et al. (1986) Influence of Age, Sex, Duration of Symptoms and Dehydration of Serum Electrolytes in Hypertrophic Pyloric Stenosis. Australian Paediatric Journal, 22, 193-197.

[14] Feng, Z., Nie, Y., Zhang, Y., et al. (2010) The Clinical Features of Infantile Hypertrophic Pyloric Stenosis in Chinese Han Population: Analysis from 1998 to 2010. PloS ONE, 9, e88925. http://dx.doi.org/10.1371/journal.pone.0088925

[15] Shanbhogue, L.K.R., Sikdar, T., Jackson, M., et al. (1992) Serum Electrolytes and Capillary Blood Gases in the Management of Hypertrophic Pyloric Stenosis. British Journal of Surgery, 79, 251-253. http://dx.doi.org/10.1002/bjs.1800790322

[16] Touloukian, R.J. and Higgins, E. (1983) The Spectrum of Serum Electrolytes in Hypertrophic Pyloric Stenosis. Journal of Pediatric Surgery, 18, 394-397. http://dx.doi.org/10.1016/S0022-3468(83)80188-2

[17] Czeizel, A. (1972) Birthweight Distribution in Congenital Pyloric Stenosis. Archives of Disease in Childhood, 47, 978-980. http://dx.doi.org/10.1136/adc.47.256.978

[18] Doenecke, D., Koolman, J., Fuchs, G., et al. (2005) Karlsons Biochemie und Pathobiochemie. Georg Thieme Verlag, Stuttgart, New York.

[19] Muntau, A.C. (2007) Intensivkurs Pädiatrie. Urban \& Fischer, München.

[20] Saba, T.G., Fairbairn, J., Houghton, F., et al. (2011) A Randomized Controlled Trial of Isotonic versus Hypotonic Maintenance Intravenous Fluids in Hospitalized Children. BMC Pediatrics, 11, 82. http://dx.doi.org/10.1186/1471-2431-11-82

[21] Lehnert, W., Schenck, W. and Niederhoff, H. (1979) Isovaleric Acidemia Combined with Hypertrophic Pyloric Stenosis. Klinische Pädiatrie, 191, 477-482.

[22] Shumake, L.B. (1975) Postoperative Hypoglycemia in Congenital Hypertrophic Pyloric Stenosis. Southern Medical Journal, 68, 223-224. http://dx.doi.org/10.1097/00007611-197502000-00024

[23] Roman, A. and Burmeister, W. (1978) Hypokalemia in Infants Due to Disturbed Salt, Water and Acid-Base Balance. Klinische Pädiatrie, 190, 108-117.

[24] Lorenz, J.M. (2008) Potassium Metabolism. In: Oh, W., Guignard, J.P. and Baumgart, S., Eds., Nephrology and Fluid/Electrolyte Physiology: Neonatal Questions and Controversies, 2nd Edition, Saunders/Elsevier, Philadelphia, 54-65. http://dx.doi.org/10.1016/B978-1-4160-3163-5.50009-9

[25] Pappano, D. (2011) Alkalosis-Induced Respiratory Depression from Infantile Hypertrophic Pyloric Stenosis. Pediatric Emergency Care, 27, 124. http://dx.doi.org/10.1097/PEC.0b013e318209af50

[26] Tigges, C.R. and Bigham, M.T. (2012) Hypertrophic Pyloric Stenosis: It Can Take Your Breath Away. Air Medical Journal, 1, 45-48. http://dx.doi.org/10.1016/j.amj.2011.06.009

[27] Smith, G.A., Mihalov, L. and Shields, B.J. (1999) Diagnostic Aids in the Differentiation of Pyloric Stenosis from Severe Gastroesophageal Reflux during Early Infancy: The Utility of Serum Bicarbonate and Serum Chloride. The American Journal of Emergency Medicine, 17, 28-31. http://dx.doi.org/10.1016/S0735-6757(99)90009-8

[28] Henderson, B.M., Schubert, W.K., Hug, G., et al. (1968) Hypoglycemia with Hepatic Glycogen Depletion: A Postoperative Complication of Pyloric Stenosis. Journal of Pediatric Surgery, 3, 309-316. http://dx.doi.org/10.1016/0022-3468(68)90016-X

[29] Pierro, A., De Coppi, P. and Eaton, S. (2012) Neonatal Physiology and Metabolic Considerations. In: Coran, A.G., Adzik, N.S., Krummel, T.M., et al., Eds., Pediatric Surgery, 7th Edition, Elsevier/Saunders, Philadelphia, 89-107. http://dx.doi.org/10.1016/B978-0-323-07255-7.00006-4

[30] Dutta, S., Lodha, R., Kabra, M., et al. (2000) Persistent Hypoglycemia with Pyloric Stenosis. Indian Pediatrics, 37, 890-893. 
Scientific Research Publishing (SCIRP) is one of the largest Open Access journal publishers. It is currently publishing more than 200 open access, online, peer-reviewed journals covering a wide range of academic disciplines. SCIRP serves the worldwide academic communities and contributes to the progress and application of science with its publication.

Other selected journals from SCIRP are listed as below. Submit your manuscript to us via either submit@scirp.org or Online Submission Portal.
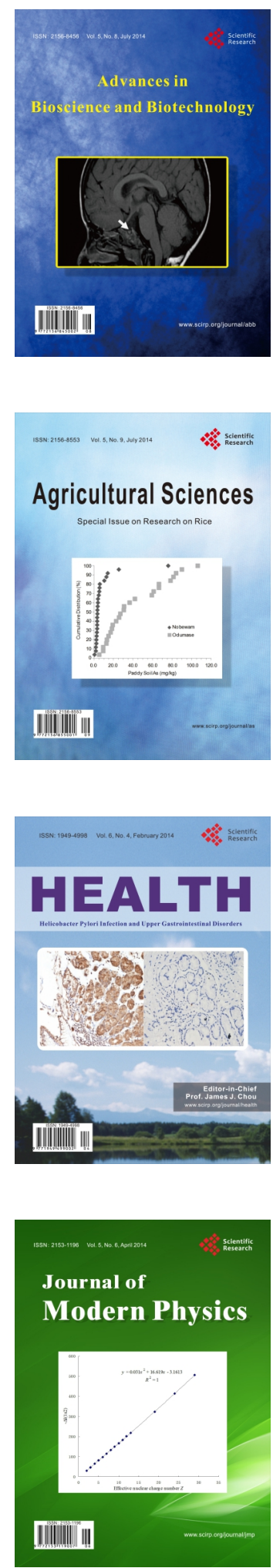
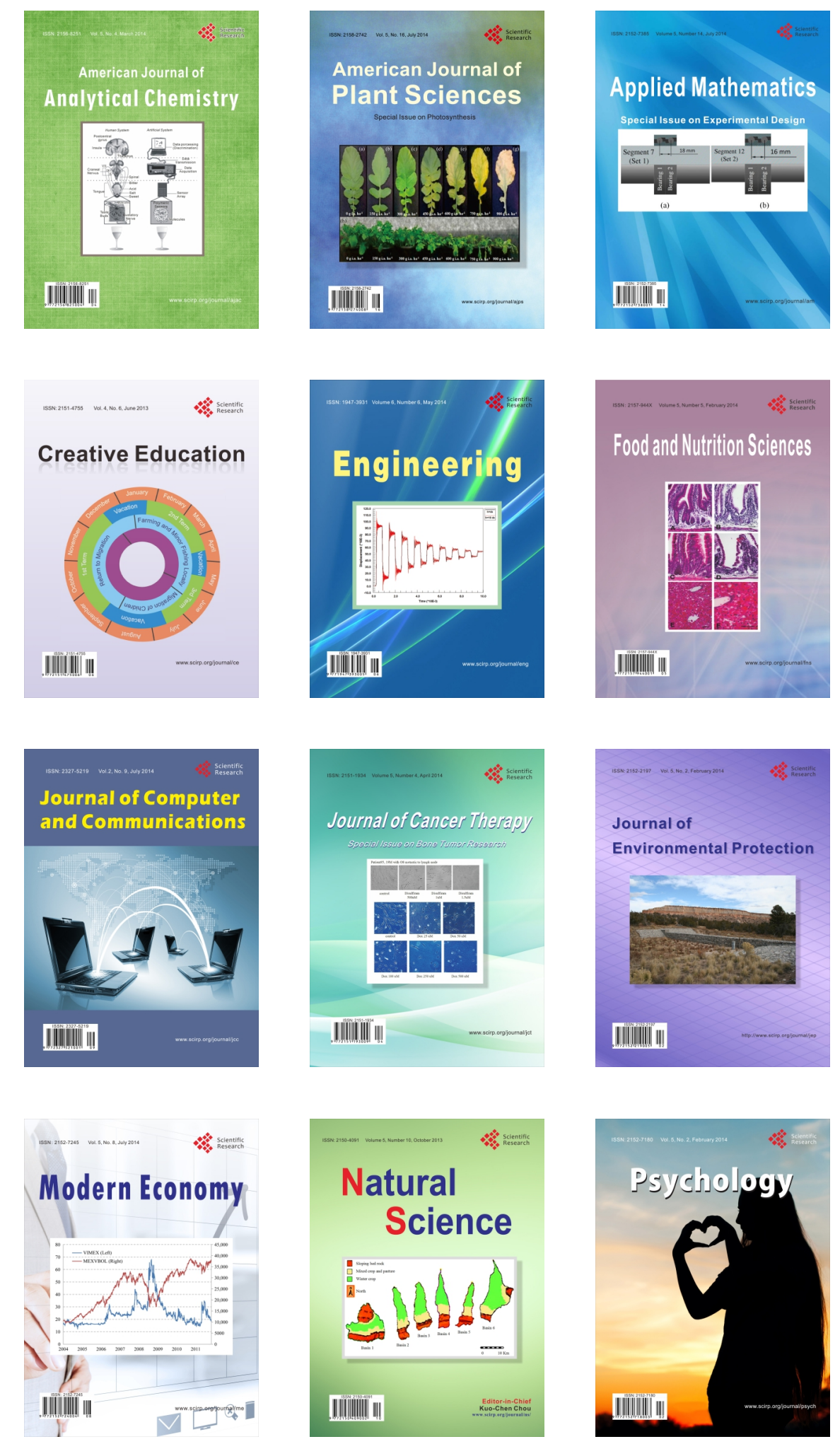